\section{The Ambiguity of Punk Women 'Masculinity' in Kuehnert's I Wanna Be Your Joey Ramone and Castellucci's Beige Novel}

\author{
1 Ellita Permata Widjayanti \\ 2 Tarascania Audina \\ 3 Andrian Santosa
}

123 Universitas Negeri Jakarta, Indonesia

\begin{abstract} the community.

\section{Keywords}

punk women hegemony masculinity ambiguity
\end{abstract}

Punk constitutes a subculture that is perceived as an androgyny community in which there is no clear difference between men and women. However, this androgyny matter is questioned by the sexism that occurred through hegemonic masculinity. This study aims to see how the femininity of punk women intertwined with the hegemonic masculinity and to see the resistance to the hegemony in Kuehnert's I Want to Be Your Joey Ramone and Castellucci's Beige novel. The method used is descriptive analysis with the theory of hegemony masculinity. The results of this study indicate that hegemonic masculinity in punk is constructed through social structure and rock music. The resistance of women gets a rejection from both punk men and women themselves. The masculinity of punk women then raises the ambiguity of their position and role in

\section{Ethical Lingua}

Vol. 7, No. 1, 2020

ISSN 2355-3448 (Print)

ISSN 2540-9190 (Online)

Corresponding Email

Ellita Permata Widjayanti

ellita.permata@gmail.com

Article's History

Submitted 7 February 2020

Revised 19 February 2020

Accepted 20 February 2020

DOI

10.30605/25409190.158

Copyright (๑) 2020

The Author(s)

This article is licensed under CC BY-NC-SA 4.0 License 


\section{The Ambiguity of Punk Women 'Masculinity' in Kuehnert's I Wanna Be Your Joey Ramone and Castellucci's Beige Novel}

Punk is a postmodern sub-culture that deconstructs the values and norms that become conventions in society through lifestyles and musical genres. This sub-culture originated in the anti-government movement in England in the 1970s. High inflation, high unemployment and lower standards of living led to the despair of the British people. The young English became angry with the government for this condition and also to the society that was too dependent on the government that unable to help its citizens and protect them from the hardships of life (Errickson, 1999, p. 8).

The anger of young Englishmen who formed the Punk sub-culture was manifested by mocking authentic cultural symbols as well as existing capitalism by making alternative ways of life voiced through the media in an unusual way (Moore, 2004). Punk irreverence also targets religion, sexual norms, consumerism and celebrity (Prinz, 2014, p. 585). Punk is then identical with anti-institution, anti-monarchy, anti-religion, anti-status quo, and establishment. They stand against the traditions, values, and norms that apply to mock them (Errickson, 1999, pp. 8-9).

Not only men, but this community also consists of women. They join the Punk community generally because they want to run away from their homes, for the reasons of having a Punk boyfriend, or just love the appearance of Punk (Errickson, 1999, p. 21). Besides, they feel like finding a home where the people in it are willing to accept them and help them to survive. The Punk community gives them the space to be free to do whatever they want. Usually, they come from a troubled family or from those who have felt the negative treatment because of their female attributes (Brake in Errickson, 1999, p. 21).

In appearance and attitude, Punk women negotiate their femininity with Punk masculine environment. This negotiation makes them look very masculine as other Punk members, so that feminine and masculine become unclear in this community. Punk in England, according to Fox (via Errickson, 1999, p. 20), is the most androgynous community, there is no clear distinction between men and women because of their similarity in appearance.

However, the label as an androgyny community does not necessarily make women's positions truly equal. In many situations, they still perform their role as women in general, such as cleaning the house or caring for a drunk man (Errickson, 1999, p. 22). Bodansky (2013) also states that in terms of music, although Punk Rock shows anti-mainstream, women are not much involved, which shows the strength of the structure of sexism as the mainstream cultural constructs. This can be influenced by the hegemonic power of masculinity in the Punk community itself.

The concept of masculine hegemony suggests that men are considered masculine when showing aggressiveness, strength, dominance over women. Hegemonic masculinity can be defined as "the dominant position of the men and the subordination of women." (Connell, 2013, p. 257). Hegemony does not necessarily mean violence; hegemony means the power of domination acquired through culture, institutions, and persuasion (Connell, 2013, p. 832). 
The subordination of masculine hegemony made Punk women establish their rock band. Rebel Grrll and Riot Grrrl are famous female punk rock bands in the 90s. Their existence is proof of how women break the hegemonic masculinity in Punk rock music and create feminism a la Punk.

The goal of Punk feminism is equality with men. This objective is similar to that of second wave of feminist ideologies such as gaining equal access in music and expanding the possibilities for women to display alternative femininity (Klein, in Barkers, 2012, p. 15-16). The second wave of feminists has found a lot of opposition from the younger generation of punk women who still want the role of men on their stage. This is the finding of Barker's (2012) in his article entitled Rock against Gender Roles: Performing Femininities and Doing Feminism among Women Punk Performers in the Netherlands, 1976-1982.

The clash between Punk women marks the third wave of feminist influences. The third wave of feminists tries to loosen restrictions and allows for various experiences and choices of women (Mann \& Huffman, in Bondansky, 2013, p. 11). Women should be free to live their lives without the pressure to adhere to the strict definition of a "feminist" lifestyle, away from radicalism and approaching liberalism. The emphasis is on individuality and personal choice, which can strengthen existing power structures (Bondansky, 2013, p. 11).

The discussion of the femininity and hegemonic masculinity of the Punk community is not only done in the factual realm, but also in the realm of fiction. Jokinen (2014) sees Punk's life in John King's Human Punk novel. He found that the main character constructs the hegemonic masculinity through repetitive behavior and subordination such as sexism, racism, and homophobia. Women in this novel are also dichotomized as sexual servants. This study, however, does not address how women's resistance to hegemonic masculinity.

From the background, the question of how the female Punk femininity is intertwined to the hegemonic masculinity, the resistance toward the hegemony and how the reaction of other Punk men and women to the resistance becomes interesting to be studied in fictional material because after all the literary work is a reflection that reflects the culture.

\section{Method}

The identity and ideology of the Punk community, including the life of Punk women, is reflected in the American Young Adult Literature entitled I Want to Be Your Joey Ramone (IWBYJR) by Stephanie Kuehnert (2008) and Beige by Cecil Castellucci (2007). Both novels received high appreciation in the international online reader site, Goodreads, which was then eligible for review.

Both novels became the material objects of this research. The data used are phrases, clauses, and sentences that show masculinity in the identity of Punk women, as well as the attitude and reaction of them to the hegemonic masculinity in the Punk community. The theory of hegemonic masculinity enriched with feminist theories and some supporting theories about Punk was used to analyze data. This research is expected to deepen and broaden the point of view of Punk sub-cultural identity in general and especially Punk women in literature as a reflection of the existence of Punk in the world community. 


\section{Results \& Discussion}

When joining the Punk community, women negotiate her femininity with the hegemonic masculinity that has been built in such a way in the community. They conduct masculine lifestyle and reject the feminine culture tradition that judges them by their beauty and elegance of appearance and behavior. It is shown through the narrative and dialogue of the characters in Beige and I Wanna Be Your Joey Ramone novels. How Punk women negotiate themselves with masculinity as a part of Punk community is explained in three subtitles below.

\section{Punk women masculinity}

Clothing is a symbolic object created to form unity among people who have close relationships and the same experience (Hall, in Hebdidge, 1979, p.121). Punk members are identical to dark-colored clothing with rough and cussed sayings, torn and shabby pants that show their identity. This style of Punk dressing is shown in Beige and IWbYJR novels as follows.

She is sporting her usual outfit of black jeans and a tight T-shirt. She wears black very time I see her pretty much. It makes her look kind of doom and gloomy. (Beige, p. 115)

She wore artfully ripped jeans and a Smith T-shirt she'd rescue from the thrift store and carefully constructed into a tank top that fit her perfectly. (IWbYJR, p. 80)

The sleeves of her leather jacket dipped to reveal a group of silver bangles that clinked together ... (Beige, p. 119)

Punk members used to wear black outfits that has been dull so it looks like it has been used many times, shabby and messy. This is done deliberately because they want to show the aesthetics of ugliness or irregularity. Soeffner (in Errickson 1999, p.13) says that Punk is an extension of the aesthetics of ugliness, perhaps some Punk looks attractive but in dress, they still try to show the quality of 'ugliness'. It aims to oppose what the mainstream cultural society considers to be a weird way of dressing. This quality of 'ugliness' is also shown by Punk women.

In mainstream society, women generally seek to look beautiful and elegant when performing in public, but this is not done by Punk women. Female characters in both novels are depicted wearing ripped jeans. According to Setyanto (2015), torn jeans are a symbol of independence for the oppression of the environment that makes the space of the Punk to be limited. Thus, ripped jeans are a symbol of their freedom of expression and freedom from the rules of a cultural construct. Besides, Punk men and women also often wear outfits or t-shirts that read harsh words or curses as contained in the following excerpts.

He's got a rolled-up cigarette hanging out of his mouth, and his skinnysleevetattooedarms poke out of his once black, now faded gray T-shirt that says NOSTRA DUMB ASS. (Beige, p. 3)

A girl with stingy thin dyed-black hair, black jeans, and a black T-shirts that says BUST on it comes up to Sam. (Beige, p. 46)

In the first quotation, there is the word NOSTRADUMBASS on the shirt worn by the character. In urbandictionary.com the word is defined as someone who makes stupid predictions about a future event that obviously will not be real, or someone who cannot reasonably judge the direction of a particular situation. However, in the quotation NOSTRADUMBASS is split into 
three parts, namely 'NOSTRA', 'DUMB' and 'ASS'. 'NOSTRA' has no clear meaning (but it can be associated with terms in music or religion), 'DUMB' means 'fools' and 'ASS' means 'butt'. The last two words are often used by young Americans to throw a swear. In the second excerpt, there is a BUST word on a T-shirt worn by Punk women. The slang term is associated with 'breast' or 'orgasm' (urbandictionary.com).

The way women dress Punk does not emphasize the feminine side as constructed in mainstream culture. Some Punk women also wear skirts but with dark colors or with motifs that seem fierce like a leopard motif (Beige, p. 252). The style of female characters dressing in this novel is more to the side of masculinity. According to Haenfler (in Griffin, 2012, p. 70), women in the Punk community will get pressure from other Punk members if they appear in a mainstream way. This means that in this community, the similarity in appearance style becomes very important to show their identity.

Not only through the way of dressing, but the hair style of Punk women are also similar to the male. They do not hesitate to shave their hair in the style of Spike or Mohawk with striking colors. This is illustrated in the following excerpts.

Regan fingered her hair, cut short, and spiky again and currently dyed blue. (IWbYJR, p. 247)

Regan's expression sobered and she start twisting her magenta hair nervously around her finger. (IWbYJR, p. 153)

Everyone's hair is dyed in a rainbow of shades and they all have tattoos." (Beige, p. 42)

Hebdige (2002, p.179) and Errickson (1999) say that the color of rainbow hair is considered as decoration and the form of real change and separation to society. Their goal is to be mindful and have their own identity that is contrary to the cultural constructs of the communities in which they live.

Symbols that are also owned by Punk women as men are tattoos. The narrator in the IWbYJR novel states "The perfect rock $n$ roll setting filled with so many scruffy, tattooed, colorful rock $\mathrm{n}$ roll people." (p. 80), which illustrates that the perfection of rock $\mathrm{n}$ roll is the attendance of tattooed people. So, tattoos are not only used as body decoration but as identity formation as part of Punk rock and roll music.

According to Bell \& Valentine (in Griffin, 2012, p.69), modifying parts of the body with a tattoo can symbolize an outlet of a person against social problems in his life because he feels helpless in the face of his problem so he vents the emotion to his body. In addition, the tattoo is also considered a symbol of power against the body/ physical and is also a resistance to pain (Setyanto, 2015). According to Firmansyah (2013), the way the Punk community expressing through the dressing style, hair color and hairstyle accessories, and tattoos is a behavior that symbolizes anti-establishment.

The similarities in the various attributes and lifestyles of Punk's men and women make the individual gender identities are not necessarily redefined, but the combination made it difficult to explicitly define some individuals as masculine or feminine (Sokol, p. 14). This is confirmed by Fox (in Errickson 1999, p. 20) and Crimeth Inc (in Nicholas, 2007, p. 3) which states that the Punk community is one of the androgyny communities where there is no clear distinction between men and women, especially in appearance. 
Nevertheless, the various symbols and meanings embodied in the Punk-looking manner tend to be of the nature of aggressiveness, power, power, and rebellion, which in the global cultural construct indicates the nature of masculinity. Thus, women in Punk are considered to adapt the values of masculinity to survive in the community so that they unknowingly erase their femininity values (Leonard in Bodansky, 2013, p. 21). For those who are extremist tomboys, they even identify themselves as men, claiming power like them and wanting respect as men (Paechter, 2006, p. 9-10).

Punk women form a masculine image on their appearance, showing that they enter the realm of masculinity and at the same time they reject the feminine hegemony that constructs women to look elegant in feminine clothing and makeup (beautiful with cultural construct standards). Not only in terms of attributes, but the femininity of Punk women also negotiates with all Punk lifestyle such as smoking, getting drunk, and taking drugs to be part of Punk. For mainstream society, their makeup and behavior are considered dangerous, and stereotyped as "unfeminine" and "inappropriate" (Batt, 2014, p. 53).

The rejection of femininity constructs is also shown in the way they apply makeup on their face. They choose dark color as black eyeliner (Beige, p.11) and dark eye makeup streaky for their daily appearance. According to Setyanto (2015), eye shadow is a symbol of Punk's perspective on the future. Dark eye shadow symbolizes a gloomy future so they are born to become a society of the lower classes during their lifetime.

If women generally use makeup to beautify themselves and as a means of attention, feminists consider it a tool of women's oppression. Punk women are not on both views. They use it as a way of self-empowerment (Mann \& Huffman in Bodansky, 2013, p.14). The Beauty Department website that appears as a third wave feminist website calls cosmetics as a skill or artform, which is done for fun rather than attracting men (Bodansky, 2013, p.14). The cosmetics they use just function to express themselves. The ultimate goal is to show the creativity and art, not to make themselves attractive and desirable for men or even to compete with other women (Baumgardner \& Richards, in Bodansky, 2013, p.14).

In music, they also feature a performance that is not meant to display beauty or to satisfy the male gaze (Wilson, 2004, p. 59). With ugliness, madness, aggressiveness, and anger, they want to show that all of these characters belong not only to men (Raha, in Batt, 2014, p. 55). Thus, the women's femininity of Punk has been deconstructed and melded into the hegemonic masculinity. They reinforce their identity with their appearance style and lifestyle perceived by mainstream culture as masculine.

\section{Hegemonic masculinity to women punk 'masculinity'}

In a capitalist society, women are only made as sexual objects and their existence is not very meaningful in society. They are often regarded as inferior. Yet they also have the same rights as men to be recognized (Wright, 2015, p. 53).

Punk is a community that has the anti-capitalist ideology. They oppose the existence of capitalist hegemony in the Punk music industry. However, in the IWBYJR novel, Punk women are described as sexual objects and treated like toys for men, especially for rock musicians. A Punk female character in the novel states "I was no longer, Emily Black, toy of the rock Gods" (p. 38). 'Toy of the rock Gods' in the quotation means a prostitute for rock musicians. The author uses 'toy' diction that affirms women in Punk is only considered a good that anyone can play. That is, women in this case, are marginalized who have no power in the 
hands of men, and this becomes a culture in the Punk community, especially rock musicians. They have free sex after performing on stage and they just choose the women they like to be sexual objects. Since women are only sexual objects, they often become victims of sexual violence as happened to the female Punk character in as illustrated in the quotation below.

\begin{abstract}
He brutally shoved her to the floor, her knees bashing against the concrete. She tried to scramble to her feet, but he pushed her down again. Her head banged into the underside of the rusty sink and she rolled onto her back, clenching the top of her head in pain." (IWbYJR, p. 124-125)
\end{abstract}

He slammed her around the grimy bathroom like a rag doll, jamming himself into her for what felt like an eternity. (IWbYJR, p. 125)

"I fucked her. So hard that she won't ever think about fooling around with Michael Black again." (IWbYJR, p. 126)

The above excerpt describes how Punk women experienced sexual violence from her own boyfriend. Punk men do not care about the violence they are doing. Women are treated as if they were just playable dolls to and fro. Of these behaviors, victims of sexual violence feel traumatized. Punk female character who became a victim of sexual violence symbolized the incident that happened with her by the 'darkness' or a very grim period in her life and very not easily forgotten. Women may feel that they have found a home in the Punk community, but this house is really no different in terms of the social structure of mainstream culture. "Even in Punk subculture, young women are expected to maintain an allegiance to their men, regardless of their sexual demands or junkie behaviors" (Pfeffer in Errickson, 1999, p. 21).

In the case of music, the role of women in Punk Rock $n$ Roll is limited only to singers backing up or playing bass, rather than being the lead vocalist or guitarist in the Punk rock band. Women are also ignored when it comes to rock music as contained in the following excerpt.

"I'm ignored all the time in music stores because I am a girl, and I think that sucks," she informs him. (Beige, p. 80)

This quote indicates that a woman's character gets discriminated as not being served or ignored in a music store because she is only considered a woman who does not understand at all about Punk music. This resulted in a lack of women's knowledge of Punk music which has implications for the least female representation in Punk music.

The limitation of women's role in rock music is because rock music is considered a genre of masculine music as it is produced and consumed by most men (Cohen in Bodansky, 2013, p. 26). When rock and roll music is performed, in general, the musicians always display a masculine image, which further strengthens the perception and correlation between rock and masculinity (Bodansky, 2013, p. 26).Rock music is displayed in a very loud tone accompanied by shouts and singing styles filled with physical movements as illustrated in the following quotation.

I try to covering my ears even more as the volume seems to go from level eight to level twelve. (Beige, p. 48)

And then he crashes his sticks on the drums. Smashes them. They explode. Like they are bombs. Sam Suck is no longer the quiet gentleman that I met by the guacamole. He's screaming. He is all noise and insanity. He is all jumping and falling and throwing and attacking the air with his body. He's all danger and pain. (Beige, p. 52) 
Based on the above quote, the flow of Punk rock music has distinctive characteristics. Punk music volume is very loud with the shouts of the band's vocalists as well as the harsh words and cries of exclamation on the stage. They also perform massive body movements. Hanscomb formulated the characteristics of Punk rock with nihilistic, extreme, passionate, free, inclusive, amateur and violent (Hanscomb, 2010, p. 1).

Punk rock music is full of symbols of aggressiveness and rebellion, which is attached to the masculine character. Continuous symbols are repeated in action, style, and expression and thus construct a masculine term (Butler, 1990, p. 178). Rock is a symbol of masculinity, so anyone involved in it must be able to show the same symbols. This then spawned the hegemonic masculinity in rock music. When women join rock music dominated by symbols of masculinity, they will be regarded as 'one of the men', not as a female performer (Leonard, in Bodansky, 2013, p. 26).

However, the existence of the marginalization of Punk women in the case of music contained in the novel indicates that femininity is not denied. The status of the female sex becomes an important thing to then deny their existence to enter in the realm that is considered masculine.

This then goes against the Punk label as the androgyny community described above. That is, although Punk women have become part of the hegemonic masculinity (with masculine appearance), gender bias still occurs especially in the case of music. Women are subordinated because they are still women with feminine construction attached to them, so they are considered unsuitable to be in a very masculine Punk rock and roll music. Hegemonic gender ideas soak many aspects of society, even deviant groups. The punk subculture is not immune to the effects of hegemonic thinking regardless of its apparent opposition to tradition (Sokol, p. 14).

The repression and marginalization of women in the Punk community affirm the existence of 'power relations, which is "the main axis of power in the contemporary European / American gender order is the overall subordination of women and the dominance of men" (Connell, 2013, p. 254). The men in this matter, by his power, conduct hegemonic masculinity towards women and treat them as an object, not a partner, even though they are in a community considered 'androgyny'.

Apart from the controversy over the androgyny perception above, there is an interesting thing about Punk women. In the novel IWBYJR, Punk women make free sex as their own pleasure, especially if the sex is done with rock musicians (Rock Gods or Rock Star), as illustrated in the following excerpt.

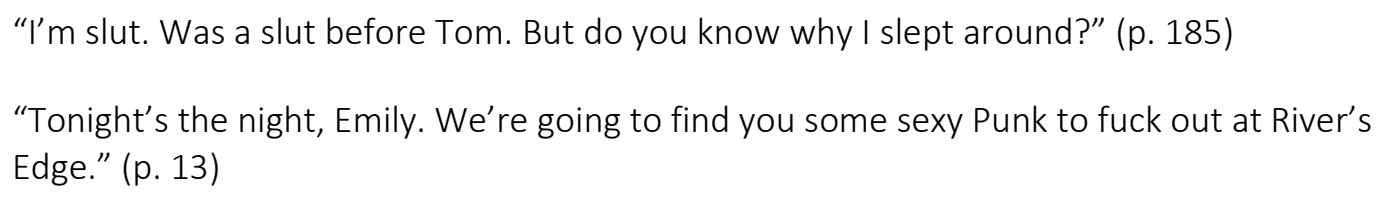

The quote above confirms that it turns out that Punk women on the other hand place themselves as subjects who have the right to choose to sleep with someone they want. They love and enjoy it because for the free sex is also one way to get out of problems other than rock and roll (IWbYJR, p. 12). The female character Punk in the above quotation also declares himself as a slut (prostitute). They are proud to call themselves sluts as long as they make love with rock musicians. 
The pride as a slut reflects the feminist character of the third wave. If the second wave of feminists is fighting for the right of adult women to be called and considered as 'woman' and not girls, the third wave feminists actually recognize the term girl in other derogatory terms such as 'bitch', 'cunt' and 'slut' (Bondansky, 2013, p. 13). The third wave of feminist groups was later known as girlies.

Girlies, according to Baumgardner \& Richards (in Bondansky, 2013, p. 14) are women in their twenties or thirties who react to anti-feminine as an inheritance of the second wave. Girlies reclaimed feminine things that were disparaged by previous waves, such as knitting, pink, nail polish, and the search for pleasure. On the other hand, they also claim rights to cultural space that are considered as the domain of men such as rock and roll music, porn, sex and pleasure free from judgment.

The term slut in Punk is also close to the term groupie which is also mentioned by the female character Punk in the novel IWbYJR. She said, "I wanted to climb up on stage and scream that I was not a groupie." The statement that she wanted to climb to the stage (rock and roll music) and that she was not a groupie anymore indicates that groupie is perceived negatively by the speaker (a Punk woman).

Groupie is a fanatic fan group on a musician or music bands. The word groupie in the United States is used as a mockery term to describe certain types of female fans who are considered more interested in having sex with rock stars than their music. Among them, there are those who only want short sex with rock musicians, and some are choosing the role of a girlfriend or surrogate mother. They also often help to keep valuables belonging to rock musicians and to accompany their social life (https://en.wikipedia.org/wiki/Groupie).

Thus, the existence of groupie explains the other side of Punk women; that some of them are marginalized directly with sexual violence and not involved in Punk rock and roll music, but some of them also enjoy the existence as a slut for their idol rock star music. This means that they are aware and indeed seek sexual pleasure with men without having to feel repressed by hegemonic masculinity. In fact, they are also happy to take on their feminine role by being a girlfriend or surrogate mother for rockers. By Connell (in Schippers, 2007, p. 87) this condition is referred as 'emphasized femininity', which is defined as "one form [of femininity] is defined as a complaint with this subordination and is oriented to accommodating the interests and desires of men." Punk women who take the roles as groupie or slut are then constituted an emphasized form of femininity that perpetuates the hegemonic masculinity.

\section{The resistance of punk women}

"Power is the crucial factor in hegemonic masculinity and resistance ensures that many sites are ones of ideological struggle for contested senses of masculinity" (Beynon, 2002, p. 16). The existence of marginalization of Punk women especially in music make them resistant from these conditions. The position as a groupie and slut makes some Punk women feel subordinated.

According to Kramarae (in Huber, 2010, p. 66), to become a dominant group, women must change their perceptions so that their status can be equal with men. In order for their existence to be acknowledged by society, they must change their perceptions as merely sexual objects for men. They must have a purpose in life. They must build a movement in their lives to fight for their rights. 
In the novel IWbYJR, the Punk female character is determined to become the god of rock (Rock God) and stop being a slut. She wants to prove that women in Punk are not just a groupie. They can even make men as groupies from their bands. Although it is difficult, she did not stop his ambition in order to fight for women's rights to be recognized in the existence of Rock music. This is consistent with feminism thinking that encourages women to enter the masculine realm like rock music. The second wave of feminists creates a special anticommercial and anti-hierarchical female space where women can display different feminine configurations (Skinner in Barkers, 2012, p. 2).

Like the second wave of feminist movements, Punk women want to free themselves through rock and roll music, because through the music they can voice themselves without the shadow of male power. This is in line with the desire of Punk music that is to change the world; the desire to live not as a historical object but as a perpetrator of history (Marcus in Errickson 1999, p.14). Punk music invites everyone to dare to vote or act to reject mainstream culture. Music is a tool to express feelings so that the game should not be set by anyone (Firmansyah, 2013).

Similar to what the female character Punk does in the IWbYJR novel, the female character in Beigenovel also very much wanted to make her own band and had a tour of her own music. The desire was done without asking for help from others. She made his own lyrics and music, promoted her own band and made her own concert. Her seriousness to become a rock music star is shown in her following statement.

\footnotetext{
“They don't take it seriously. They do it more for the look....I'm going to take over the world. This winter I'm going to record. Next summer, I'm going to go on tour. Mark my words. Tour equals adventure time." (Beige, p. 207)
}

This shows that Punk women are trying to get out of male domination as well as trying to build their own musical careers. They build a new feminine configuration. Despite their masculine appearance, they still represent women in their style, appearance, and music. They translate the female feminine concept of Punk with the identity of Punk masculinity attached to them. The purpose of the Punk feminist is similar to that of the second wave of feminists, which is equal to men in terms of access to the music stage and expands on the possibility of women to display alternative femininity (Klein in Barkers, 2012, pp. 15-16). Punk women reject the concept of what women can and cannot do and tend to perform functions that transcend the limits of women in general that are tied to cultural construct (Batt, 2014, p. 54).

The existence of Punk female resistance is also in line with the ethics of Do It Yourself where Punk musicians emphasize more on the process of music production apart from the capitalist music industry dominated by famous record labels. With this ethics, they are principled to do anything with their own abilities (Moran, 2011). They believe that musicians do not have to rely on payments from other people (especially men). They can do the production and distribution of their music and promote it through their own efforts.

The female Punk character in the Beige novel is very proud of her identity as Punk and is not afraid to voice her aspirations with music and to do something for herself, not to please others as in the following quotation.

My name is Lake Suck and this is my manifesto. I swear to be myself. To think for myself. I will not led by social conventions. I will make my own way through the world. I will live my own terms without conforming to society's expectations of who they think I should be. I 
will be the visible minority. By being myself, I will help to save the world. I swear to always look, listen, learn, think, ask, act and speak for myself. (Beige, p. 226)

The quote above shows that to get out of the hegemonic masculinity, Punk women have to do it by their own hands. This quote also shows that Punk women want to be a visible minority and not immersed in the rules of mainstream culture. She even tried to break the mainstream cultural constructs that are still inherent in the Punk community; namely the subordination of women. Connell (in Schippers, 2007, p. 87) terms it as the form of femininity which is defined by non-compliance.

However, this resistance gets resistance from the masculine group. They still believe that women are not worthy of rock and roll music. Although women participate in music, they believe that women will not be as good as men. A male character asked a Punk woman who would set up a rock band "Do you sing as good as you suck dick?" (IWbYJR, p. 45). This question shows how men despise women in Punk. They just think women cannot equate to them (as rock musicians). The implicit message is that women are just great in sex and do not deserve to be rock musicians.

Unfortunately, the rejection is not only from men, but this resistance is also not supported by the fellow of female Punk. This is illustrated in the following excerpt from Beige novel.

The other girls are talking to boys. They aren't interested in the nitty-gritty of being in a band. Just the glory. That's why I helped with the flyers.

The quote above shows that many Punk women are apparently not interested in getting out of their comfort zone in the hegemonic masculinity. They are those who feel comfortable with the role of slut and groupie because they get pleasure with that position. They do not even think that their position is a form of marginalization of the hegemonic masculinity. It also shows that the resistance of some Punk women to the hegemonic masculinity does not get the full support of the entire Punk female population. Their resistance also gained resistance from both men and women.

\section{Conclusion}

In Punk community, the women negotiate their femininity with Punk masculinity. However, they are not fully accepted as masculine entities. They continue to act be like women in mainstream culture. They are also mentally and sexually repressed. They experience sexual violence and are subordinated to the restrictions of the male and female domains. In this community, the hegemonic masculinity is produced through repetition of the action they perform in music and through their social structure within the Punk community.

Punk women do resistance with rock music to get equality with men. This is done because all the time they only act as s/ut and groupie; a very low role for them. However, this resistance gets scorn from men Punk men who assume that women will not be as good as men in music, as rock music is a very masculine realm. This resistance is also rejected by some fellow female Punk. They refuse to join because they stick with the status quo that makes them happy and comfortable to be slut and groupie without feeling marginalized.

This condition creates ambiguity in the 'masculinity' of Punk women. They reject the hegemony of femininity by making themselves part of the hegemonic masculinity. However, they are also hegemonized in it because they remain women with the construction of duties 
and the role of femininity as mainstream cultural constructs. That is, even though they are already 'masculine', they remain 'feminine' with the duties and functions to be given to them by the Punk community. When they want to get out of the hegemonic masculinity, they are rejected not only by men, but also by their fellow. This ambiguity makes the resistance of Punk women in an unclear condition and position. They then do not fully become masculine and not entirely feminine. The second wave of feminism then calls this ambiguity the alternative femininities.

For the other researchers who want to examine the same object, it is suggested to look deeper on how alternative femininity works in Punk community or the other subculture communities.

\section{Acknowledgement}

N/A

\section{References}

Batt, A. (2014). Bubblegum Girls Need Not Apply: Deviant Women the Punk Scene. The Undergraduate Journal of the Athena Center for Leadership Studies at Barnard College, 2(1), 52 - 62. Retrieved from https://academiccommons.columbia.edu/catalog/ac:206777

Berkers, P. (2012). Rock against gender roles: Performing femininities and doing feminism among women punk performers in the Netherlands, 1976-1982. Journal of Popular Music Studies, 24(2). 156-174. https://doi.org/10.1111/j.1533-1598.2012.01323.x

Beynon, J. (2002). Masculinities and Culture. Buckingham and Philadelphia: Open University Press.

Bodansky, R. L. (2013). "Rebel Girls: Feminist Punk for a new generation”. Senior Theses Paper 199. Retrieved from http://scholarship.claremont.edu/scripps theses/199.

Butler, J. (1990). Gender Trouble: Feminism and the Subversion of Identity. New York: Routledge.

Castellucci, C. (2007). Beige. USA: Candlewick.

Connell, R. (2013). The Social Organization of Masculinity. In Local and Global Theory Perspective Reader, $3^{\text {rd }}$ edition. New York and London: Routledge.

Errickson, A. (1999). A Detailed Journey into the Punk Subculture: Punk Outreach in Public Libraries. University of North Carolina: Chapel Hill.

Firmansyah, F. (2013). Persepsi Masyarakat Terhadap Musik Punk. Journal of Urban Society's Arts, 13(1), 61-71. Retrieved from http://download.portalgaruda.org/article.php?article=263296\&val=7063\&title=Persepsi \%20Masyarakat $\% 20$ terhadap\%20Musik\%20Punk

Griffin, N. (2012). Gendered Performance Performing Gender in the DIY Punk and Hardcore Music Scene. 2012. Journal of International Women's Studies, 13(3). 65-81. Retrieved from http://vc.bridgew.edu/cgi/viewcontent.cgi?article=1052\&context=jiws

Hanscomb, S. (2011). Do it Yourself: Existentialism as Punk Philosophy. University of Glasgow. Retrieved from http://eprints.gla.ac.uk/54598/1/54598.pdf

Hebdige, D. (2002). Subculture; The Meaning of Style. London and New York: Routledge.

Huber, J. L. (2010). Singing it out: Riot Grrrls, Lilith Fair, and feminism. Kaleidoscope: A Graduate Journal of Qualitative Communication Research, 9(5), 65-90. Retreived from https://opensiuc.lib.siu.edu/kaleidoscope/vol9/iss1/5 
Jokinen, J. F. (2014). We're Punk Rockers, Brick Chuckers, Finger Fuckers": Masculinities in John King's Human Punk. Master Thesis in University of Eastern Finland. Retrieved from http://epublications.uef.fi/pub/urn_nbn_fi_uef.../urn_nbn_fi_uef-20140649.pdf

Kuehnert, S. (2008). I Wanna Be Your Joey Ramone. USA: MTV Books.

Moore, R. (2004). Postmodernism and Punk Subculture: Cultures of Authenticity and Deconstruction. The Communication Review, 7. 305-327. https://doi.org/10.1080/10714420490492238

Moran, I. P. (2011). Punk: The Do-It-Yourself Subculture. Social Science Journal, 10(1). Retrieved from https://repository.wcsu.edu/ssj/vol10/iss1/13

Nicholas, L. (2007). Approaches to gender, power and authority in contemporary anarchopunk: poststructuralist anarchism?. eSharp Issue 9. Retrieved from https://www.researchgate.net/publication/309010476 Approaches to Gender Power and_Authority_in_Contemporary_Anarcho-punk_Poststructuralist_Anarchism.

Paechter, C. (2006). Masculine Femininities/Feminine Masculinities Power, Identities And Gender. Gender and Education, 18(3). 253-263. Retrieved from http://research.gold.ac.uk/1551/1/EDU_Paechter_2006a.pdf

Prinz, J. (2014). The Aesthetic of Punk Rock. Philosophy Compass. https://doi.org/10.1111/phc3.12145

Schippers, M. (2007) Recovering the feminine other: masculinity, femininity, and gender Hegemony. https://doi.org/10.1007/s11186-007-9022-4

Setyanto, D. W. (2015). Makna dan Ideologi Punk. Andharupa: Jurnal Desain Komunikasi Visual \& Multimedia, 1(2). https://doi.org/10.33633/andharupa.v1i02.964

Sokol, R. (n.d.) Subbacultcha:" Gender Roles in the Punk Subculture. Final Research Project: Unobtrusive Method/Content Analysis. Retrieved from http://ronniesokol.weebly.com/uploads/9/1/7/8/91784636/qualitative research paper.p $\mathrm{df}$

Wilson, A. (2004). After The Riot: Taking New Feminist Youth Subcultures Seriously. A thesis submitted to McGill University. Retrieved from http://digitool.library.mcgill.ca/thesisfile81521.pdf

Wright, L. (2016). Do-it-yourself girl power: An examination of the Riot Grrrl subculture. James Madison Undergraduate Research Journal, 3(1), 52-56. Retrieved from http://www.jmurj.edu/vol3/iss1/6/ 